\title{
Analysis of Some Nutrition Habits of Children with Moderate and Severe Intellectual Disability
}

\author{
Didem Önay Derin ${ }^{1} 1$ Bedia Yıldırım²
}

\author{
1 Prof. Dr., Selcuk University, \\ Konya/Turkey \\ ORCID: 0000-0003-0624-5714 \\ E-Mail:donay@selcuk.edu.tr \\ 2 Dr., Ministry of Education \\ Aksaray/Turkey \\ ORCID: 0000-0002-3167-4038 \\ E-Mail: \\ bedia_1299@hotmail.com \\ Corresponding Author: \\ Bedia Yıldırım \\ January 2022 \\ Volume:19 \\ Issue: 45 \\ DOI: $10.26466 / / o p u s j s r .1063222$
}

\section{Citation:}

Önay Derin, D. and Yıldırım, B.

(2022). Analysis of Some

Nutrition Habits of Children

with Moderate and Severe

Intellectual Disability . OPUS-

Journal of Society Research, 19(45),

69-87.

\begin{abstract}
As a case study, the paper was planned and applied in order to identify nutrition characteristics of children with moderate and severe intellectual disability, some nutrition habits, and food consumption frequencies and treatments of families towards their nutrition. The sample of this research is included by 82 children and their parents at the age of 5-18 with moderate and severe intellectual disability who continue their education at Aksaray. Data of the research were collected between January-February 2018 from mothers by using questionnaires in face to face interview and some of the questionnaires were distributed and collected after making necessary explanations to some of them. Descriptive statistical analyzes such as percentage $(\%)$ and frequency $(n)$ were made by SPSS package program. Chi-square ( $\chi 2)$ significance test was used for the statistical evaluation of the data collected of this search. In evaluating the food consumption frequency, a scoring system was used, using the formula $T=5 T 1+4 T 2$ $+3 T 3+2 T 4+1 T 5$. In order to compare foods with each other in terms of frequency of consumption, the percentage is calculated between the total score set for each food item and the highest total score that if this food consume every day. $73.2 \%$ of the participants were male and $26.8 \%$ were female. Age of the children ranged from 4 to 18 , with an average of $10.71 \pm 0.52$ years. In the study, $46.3 \%$ of mothers stated that they can eat their own meal when they were asked "how does your child consume their meals?" $46.3 \%$ of them pointed that they sometimes eat with support of someone else, $7.4 \%$ stressed that they eat sometimes themselves and sometimes with the support of others. Mothers of 44 children who were unable to feed themselves stated that they can't reach the independent nutrition stage. $39.1 \%$ of them told that they polluted the environment, $37.0 \%$ indicated that they cannot keep the spoon, and $23.9 \%$ complained that it took too much time for them.
\end{abstract}

Key Words: Moderate and Severe Intellectual Disability, Nutrition, Nutrition Habits, Food Consumption Frequency.

\section{Öz}

Bir durum saptaması olan bu çalışma, orta ve ağır düzeyde zihinsel yetersizliği olan çocuk ve ergenlerin beslenme özellikleri, bazı beslenme alışkanlıkları ve besin tüketim sıklıkları ile ailelerin çocuklarının beslenme konusundaki davranışların belirlemek amacıyla planlanıp yürütülmüştür. Bu araştırmanın çalışma grubunu, Aksaray' da ĕ̆itim görmekte olan 5-18 yaş grubunda yer alan ağır ve orta düzeyde zihinsel yetersizlik tanısı almış 82 çocuk ile anneleri oluşturmuştur. Araştırma verileri anket formu kullanılarak, Ocak- Şubat 2018 tarihleri arasında karşılıkl görüşme tekniği kullanılarak Aksaray'da bulunan orta ve ağır düzeyde yetersizliği olan bireylerin eğitim aldığı okullarda velilerin bir kısmına yüz yüze uygulanmış, bir kısmına ise gerekli açıklamalar yapıldıktan sonra dağıtılmış ve toplanmıştır. Verilerin istatistiksel değerlendirmesinde SPSS paket programı ile gerekli istatistiksel analizler yapılmıştır. Besin tüketim sıklığı $T=5 T 1+4 T 2+3 T 3+2 T 4+1 T 5$ formülünden yararlanılarak puanlanmiştır. Araştırma sonuçlarına göre, çalışma kapsamındakilerin \%73.2'si erkek, \%26.8'i de

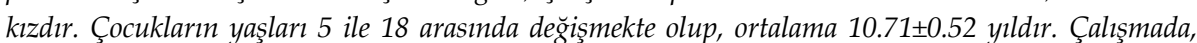
annelerin \%46.3'ü çocuklarının kendi başına yemeğini yiyebildiğini belirtirken, yine aynı oranla \%46.3'ü bazen başkasının desteğiyle, \%7.4'ü de bazen kendisi bazen de başkasının desteğiyle yediklerini ifade etmişlerdir. Kendi başına beslenemeyen 44 çocuğun annesine bunun nedeni sorulduğunda, \%39.1'i etrafı kirlettiğ $i, \% 37.0^{\prime} \imath$ kaşığı tutamadı̆̆ı ve \%23.9'u da fazla zaman aldığı için bağımsı beslenme aşamasına ulaşamadığını belirtmiştir.

Anahtar Kelimeler: Ağır ve Orta Düzeyde Zihinsel Yetersizlik, Beslenme, Beslenme Alışkanlıkları, Besin Tüketim Sıklığı.- 


\section{Introduction}

Growth and development are under the effects of factors such as nutrition, gender, genetic structure, environmental factors, socio-economic status, traditions and culture. The most important of these is undoubtedly nutrition (Vançelik et al., 2007). Nutrition (Baysal, 2007), defined as getting and using nutrients that will provide enough of each of the energy and nutrients necessary for long-term growth, development, healthy and productive life in the most economical way without losing nutritional value which has great importance in childhood and adolescence period in which physiological, psychological, social development and growth rate is very high (Köksal, 2007). Daily nutrients not only meet all the necessary nutrients to support growth and development throughout life, but also provide a balanced energy intake with energy expenditure. Adequate and balanced nutrition can protect and improve health and reduce the risk of chronic diseases (Ergün, 2003), adequate and balanced nutrition is providing exact and complete energy and nutrients which are necessary for the normal life and work of the body according to the age, gender and special condition of the individual (Aykut, 2011). Adequate and balanced nutrition is important for the development of infants, child and maternal health, the establishment of a strong immune system, reduction of the risk of non-communicable disease, and healthy aging. Malnutrition coupled with weakness in the immune system, increased susceptibility to diseases, impaired physical and intellectual disability, and reduced productivity is a serious threat to human health (WHO, 2013a; $\mathrm{WHO}, 2013 \mathrm{~b}$ ). Taking energy and nutrients to meet body needs in the recommended quantities is very important especially during the youth period. Inadequate and unbalanced feeding of young people during this period may cause malnutrition, obesity, cardiovascular diseases, anemia, vitamins and mineral deficiencies, growth and development deficiencies (Casey et al., 1992, Kapi and Bhavna, 2002). Nutrition is essential to support the quality of life of children with impaired intellectual disability, but it is often negatively affected by eating problems seen in these children (Gal et al.,
2011). Despite the fact that the life expectancy of individuals with intellectual disability has increased in recent years, the mortality rates are quite high compared to the general population. Among the causes of premature death in intellectual disability individuals there are; the severity of inadequacy, the decrease of ability to move, the difficulties in nutrition, and the presence of epilepsy (Scheepers, 2005). Nutrition related problems, which are among early causes of death, are common in individuals with intellectual disability (Jansen, 2004).

Intellectual disability was defined by the American Association of Mental Strain (AAMR) as "an inadequacy that begins before the age of 18 , characterized by meaningful limitations seen in both mental functions, concepts, and adaptive behaviors manifested in social and practical skills" (American Pyschiatric Association, 2013). Defining the intellectual disability situation plays an important role in determining the individuals with inadequacy and in providing special education opportunities in line with their needs. However, individuals with intellectual disabilities are not a homogeneous group. Since they have significant differences between each other, definition of intellectual disability does not adequately reflect these differences. For this reason, individuals with intellectual disability need to be classified according to their common characteristics (Eripek, 1996). According to the IQ levels resulting from the psychometric evaluations of the degree of intellectual disability of the World Health Organization (WHO); (IQ:52-69) is mild, (IQ:36-51) is medium and (IQ: 20-35) is deep intellectual disability (WHO, 1980). There is another classification of the American Psychiatric Association's Diagnostic and Statistical Manual of Mental Disorders-5 (DSM-5) published in 2013. According to this, the individuals with intellectual disability are classified according to their intelligence parts and they were grouped as light (IP: 50 / 55-70), middle (IP: 35 / 40-50 / 55) and severe (IP: those below 20/25) (American Pyschiatric Association, 2013).

There are many risk factors that can cause health problems in the lifestyles of people with intellectual disabilities. One of them is nutrition 
and eating disorders. Nutrition is essential to support the quality of life of children with intellectual disability and nutrition and eating disorders of children with intellectual disability, can cause malnutrition or obesity (Ünal and Özenoğlu, 2016). Particularly these individuals are at high risk for developing malnutrition (AbdAllah, 2007). The most influential factors in malnutrition are eating problems or lack of information on nutrition (Suzuki, 1991). Factors that negatively affect nutrition of children who have intellectual disability are usually related to impaired motor function. In general, the weight of malnutrition is directly proportional to the neuro developmental state (Vargün et al., 2004). Feeding, an essential adaptive function that affects quality of life of persons with the intellectual disability, is a complex sensori motor process that involves integration between the nervous system and the muscles and is affected by environmental factors. Any deficit in structure and/or function can lead to difficulties in performing feeding activities such as chewing, drinking and swallowing. These feeding problems have been linked to various disorders, including intellectual disability, and shown to affect mental, physical, social and educational development (Rezaei, 2011). Due to the motor disorder seen in children with intellectual disabilities, they cannot reach food on foot or take their food to their mouths and oral hygiene procedures such as tooth brushing, which requires skill, cannot be done adequately. For this reason, they are dependent on another person in nutrition activities. The inability of children with intellectual disabilities to use large and small muscles can have difficulties in maintaining hand-eye coordination. In addition, children with intellectual disabilities also have difficulty expressing hunger or food preferences due to speech problems. For this reason, the fact that the person who helped the child in feeding has incomplete knowledge about adequate and balanced nutrition, or lack of proper care about nutrition, causes the child to over or under nutrition (Özgüven, 2015). The impaired oral motor function seen in individuals with advanced intellectual disability and weakened muscles will also cause chewing problems. These patients are often fed with puree-like, semi-solid foods, which lead to constipation (Kömerik et al.,
2012). Constipation has also been reported as a common problem related to poor dietary fibre intake, inadequate fluid intake, and other factors that often accompany physical disabilities such as reduced mobility, low muscletone. Chronic constipation and poor bowel function is well documented as common among people with severe intellectual disability (Stewart, 2003). One of the major malnutrition problems in children with intellectual disabilities are dysphagia (difficulty swallowing) (Ünal and Özenoğlu, 2016), masticatory weakness and esophageal reflux. A study in Finland (Simila \& Niskanen, 1991) found that $64 \%$ of children with severe disabilities were under weight, due to feeding and dietary difficulties. In a study of 128 children with intellectual disability in the northwestern part of Spain, serum biochemical values of children (albumin, transferrin, ferritin, iron, calcium, phosphorus, cholesterol, HDL cholesterol, LDL cholesterol, triglycer, cide, alkaline phosphatase, transaminase and carnitine) were examined and malnutrition was found in the majority of children with intellectual disabilities according to the results (Sa'nchez-Castres et al., 2003). In addition to malnutrition, obesity seemed to be frequently observed in individuals with intellectual disability. Unhealthy eating habits and inadequate physical aktivity are the most important factors in the development of obesity (Adachi-Mejia et al., 2007). Interest in seriosness of the problem icreases year by year due to imcomplete or inadequate nutritional practices and inadequate physical activity made in early life caused by persistent obesity in the adult and many chronic diseases (Haynos and O'Donohue, 2012). A sufficient and well-balanced diet is one of the basic conditions not only for the vital activity of the individuals, but also for the improvement of a whole community. Child are the most critical periods which lifelong habits are acquired. Unhealthy diet habit is one of the risky behaviors seen during this period. Unhealthy diets in child may cause growth failure and obesity (Eker, 2018). It is stated that obesity is seen in $71.7 \%$ of individuals with intellectual disability (Köşgeroğlu, 2011). There are many risk factors that can lead to health problems in the lifestyles of intellectual disability individuals. Intellectual disability children are physically less 
active than healthy children. In these children, the level of physical activity does not reach the recommended physical activity which is at least 3 times 30 minutes per week. Therefore, the incidence of obesity is higher and the risk of comorbidities is increased due to visceral fat tissue. Obesity in intellectually disabled children and adolescents should be considered as an important public health problem that needs to be emphasized much more (Ünal and Özenoğlu, 2016). Nutritional interventions must be considered to protect against malnutrition and obesity. Nutrition tubes should be used if oral feeding is not available. Energy, protein and micronutrient intake should be routinely monitored and should be avoid from inadequate or overfeeding (Ünal and Özenoğlu, 2016). Oral nutrition (various flavor products, dietary supplements), nutrition with gastrostomy tubes and accordingly enteral nutritional products, are recommended for patients with esophageal reflux disease. Standard polymeric and concentrated polymeric enteral products can be used in these patients. These products are rich in energy, protein, vitamins, minerals and trace elements. It contains nutritional items that support the central nervous system such as carnitine, biotin, choline, inositol and taurine. Carbohydrate and protein modules from modular products can also be used with these patients. The carbohydrate modules contain malto dextrin and are easily soluble and digested by polysaccharides. They are used as an energy source in unbalanced nutrition consumption, general muscle weakness, fluid nutrition, chronic nutritional disorders and frequent infectious diseases. Protein modules are milk proteins in powder form which have high biological value. They contain high amounts of calcium and low amounts of fat. It is used to meet the increased protein requirement in growth retardation and anorexia cases in cases of general nutritional deficiencies, decreased nutrient consumption, frequent infection and decreased muscle strength (Köksal, 2008). Timimi et al., (1997) reported children with selective eating ate a largely carbohydrate-based diet. This finding was replicated by Nicholls et al., (2001), who stated the children in their study "live on carbohydrates". Another study also found starches to be far more prevalent food group accepted, with children in all group seating twice as much starches as foods from other groups (Williams et al., 2005). In a study conducted on 17 children with refractory epilepsy, the calcium, iron, zinc, vitamin B1- B2 and niacin intakes of the children were ported to be below there commended values (Bertoli et al., 2006). In a study evaluating the nutritional statuses of 50 children with intellectual disability, the protein and vitamin B1 consumption of the children were found to be higher than there commended values in all age groups (Maity and Gupta, 2010). The findings of the study indicated that all subjects were somehow involved with feeding problems. The results also show that mean score of problem in feeding skills (2.41) are most prevalent and aspiration risks (0.37) are of less prevalence among the subjects. Analyses revealed the gender and level of intellectual disability severity are effective factors in feeding problems (Rezaei et a., 2011). This finding was replicated by Hinckson et al., (2013), the nutrition and physical activity questionnairess howed healthy habits at baseline with little room for substantial improvements in most variables. The latter can be due to the limitation of self-reporting where participants report desirable answers. However, some changes in eating behaviors were maintained after 24 weeks. The most notable change was the marked reduction in the consumption of confectionary and chocolates. It seems that the program had a positive impact in changing this particular behavior (Hinckson et al., 2013). Another study, in the 10-13 age group, the folic acid and calcium intakes of girls and boys were below their commended values. In the 14-18 age group, the vitamin $C$ and calcium intakes of girls and the calcium intakes of boys were below their commended values (Nogay, 2013). The studies show that, sensory processing disorders are prevalent among children with intellectual ability and negatively impact their daily routines. Eating, which is a major part of daily routines, is known to be frequently impaired among children with intellectual abilities (Engel-Eger et al., 2016). In a Swedish study describing health concerns in persons with intellectual disability, higher incidence of several nutrition-related health 
problems was reported; iron deficiency twice as prevalent, fluid and electrolyte disturbances twice as prevalent and functional digestive problems were five times more prevalent (Sandberg et al., 2017). This study was planned and applied in order to identify nutrition characteristics of children with moderate and severe intellectual disability, some nutrition habits and food consumption frequencies (questions like food consumption patterns, whether they eat by themselves, if not the reasons why they do not, eating patterns, selective eating, the frequency of main meals and snacks, favorite meal, appetite, development, regular vitamin and mineral intake, whether they have eating disorders, if so the reasons why they have disorders, satisfaction from nutrition before they start school) and behaviors of families towards their nutrition (guestions like letting children eat whatever they want, urging children to eat even if they are not hungry, letting children eat junk food whenever they want, limiting the amount of food in next meal when they see their children over eat during a meal, how they react when their children do not finish their meal, types of rewards they resort) and a general screening model was used to investigate. For this purpose answers were search within the framework of four main titles to the questions aiming to reveal the general information about the introductory characteristics of the families, the general information about the introductory characteristics of the children, the nutritional characteristics of the children and some nutritional habits, and the effects of the mothers on the nutritional behaviors of their children.

\section{Methodology}

\section{Research Model}

As a case study, the paper was planned and applied in order to identify nutrition characteristics of children with moderate and severe intellectual disability, some nutrition habits, and food consumption frequencies and treatments of families towards their nutrition and a general screening model was used to investigate. General screening models; "in a universe consisting of a large number of elements, a screening of all or part of the universe in order to arrive at a general judgment about the universe" (Karasar, 2011).

\section{Universe and Sample}

Schools in study group include 1st and 2nd level Aksaray Special Education Application Centre and Turkish Football Federation Special Education PreSchool in which children with moderate and severe intellectual disability in the centre of Aksaray continue their education. Study was carried on the children between 5-18 because the schools in which the study was applied are state schools. Since the youngest boy in these schools is 5 , it is identified as the lowest limit. The sample of this research is included by 82 children and their parents at the age of 5-18 with moderate and severe intellectual disability who continue their education at Aksaray Special Education Application Centre 1st and 2nd Grade, Aksaray Special Education Practise Centre and Turkey Football Federation Special Education Preschool. 73\% of the participants $(n=60)$ were male and $26.8 \%(n=22)$ were female.

\section{Data Collection Tools}

Data of the research were collected between January- February 2018 from mothers whose children with moderate and severe intellectual disability take education at schools in Aksaray by using questionnaires in face to face interview and some of the questionnaires were distributed and collected after making necessary explanations to some of them. Before questionnaire form was created, related literature (thesis, essay, notice, scientific research, etc.) was reviewed and the form was prepared by researchers based on previous research and resources (Oğuz and Önay, 2011; Oğuz and Önay Derin, 2013; Turgut et al., 2014; Yildırım 2015). Questionnaire was prepared by a $\mathrm{PhD}$ student who is also an experienced teacher in a school of National Education Ministry and have various studies in the field. Then, it was sent to experts for review and the experts are among teachers working in schools of National Education Ministry and academicians from different universities. The questionnaire form information about familys' identifiying characteristics (14 
questions), information related to children' identifiying characteristics (8 questions), nutrition characteristics and some nutrition habits of children (16 questions) and some practices by mothers on nutrition habits their children $(6$ questions). In total the form consists of 4 sections and 44 questions. The questionnaire form was formed by open and closed ended questions to present some information about familys' identifiying characteristics (age, education, marital status, occupation, family type, monthly income, kitchen expenditures, number of children, whether there is a kinship between parents, whether there are any intellectually disabled members in the family, the age of mother when she got pregnant, whether she used folic acid before and during pregnancy, whether she smoked during pregnancy, delivery method), information related to children' identifiying characteristics (gender, age, weight, height, birth order among siblings, birth weight, how long they were breastfed and how often they got sick), nutrition characteristics and some nutrition habits of children (food consumption patterns, whether they eat by themselves, if not the reasons why they do not, eating patterns, selective eating, the frequency of main meals and snacks, favourite meal, appetite, development, regular vitamin and mineral intake, whether they have eating disorders, if so the reasons why they have disorders, satisfaction from nutrition before they start school) and some practices by mothers on nutrition habits their children (letting children eat whatever they want, urging children to eat even if they are not hungry, letting children eat junk food whenever they want, limiting the amount of food in next meal when they see their children over eat during a meal, how they react when their children do not finish their meal, types of rewards they resort).

\section{Data Analysis}

The results of the study were evaluated by there searchers themselves. Descriptive statistical analyzes such as percentage (\%) and frequency (n) were made by statistical package for social sciences (SPSS) package program and chi-square $(\chi 2)$ significance test was used for the statistical evaluation of the data gathered from the results of the research. Age was taken as a variable, and a p value of less than 0.05 was considered statistically significant. In evaluating the food consumption frequency, a scoring system was used, using the formula $\mathrm{T}=5 \mathrm{~T} 1+4 \mathrm{~T} 2+3 \mathrm{~T} 3+2 \mathrm{~T} 4+1 \mathrm{~T} 5$. The total scores for each food are collected by multiplying the frequency of food consumed every day by 5 , consumed every other day by 4 , consumed per week by 3, consumed every 15 days by 2 and consumed per month by 1 . In order to compare foods with each other in terms of frequency of consumption, the percentage is calculated between the total score set for each food item and the highest total score that if this food consume every day (Aktaş, 1979).

\section{Findings and Discussion}

In this section, there are discussion and findings related to the identification characteristics of families and children, the nutritional characteristics and habits of children and the frequency of food consumption.

\section{Findings About Familys Identifiying Characteristics}

$\% 65.9$ of mothers, $\% 75.6$ of fathers of 82 children with moderate and severe intellectual disability included in the study were either 35 or older. It was determined that more than half $(59.8 \%)$ of the children's mothers and nearly half $(43.9 \%)$ of the fathers were primary school graduates. Majority $(91.4 \%)$ of the mothers are housewives and nearly half $(43.9 \%)$ of the fathers are self-employed. A large number of the families $(96.3 \%)$ participated in the survey are married. $81.7 \%$ of the children have a nuclear family, $14.6 \%$ extended and $3.7 \%$ fragmented family structure. The highest number of children in the $46.3 \%$ of the families is 3 and it is followed by $2(36.6 \%)$ then 4 (6. 1\%). $6.1 \%$ of families have 5 children and $4.9 \%$ of them have 1 child.

In the study, it was determined that $24.4 \%$ of the participants in the study had members with other intellectual disabilitys in their families and relatives. It was determined that $29.3 \%$ of mothers 
and fathers included in the survey had kinship. Considering health consequences of consanguineous marriages, it has been reported that the risk of having a disabled child is higher in this type of societies than normal marriages. The incidence of severe intellectual disability, blindness, hearing impairment and deafness increases in the children of parents made a marriage of consanguineous (İnand et al., 2016). One of the important factors affecting the child's nutrition is the socio-economic status of the family. Sufficient and balanced nutrition of the child is affected by the factors such as lack of economic power, lack of education and high number of children in the family (Demirel et al., 2001). 52.4\% of the families think that their monthly income is not enough and $47.6 \%$ are glad with it. It has been determined that families mostly $(31.7 \%)$ spend 251-500 TL of their income per month for kitchen. Most of the families $(70.7 \%)$ think that their food expenditure is regular, while $29.3 \%$ do not agree.

Table1. Distribution of mothers' according to pregnancy information.

\begin{tabular}{lcc}
\hline & Number & \% \\
\hline Age of gestational & 38 & \\
$18-25$ & 27 & 46.3 \\
$26-30$ & 12 & 32.9 \\
$31-35$ & 5 & 14.6 \\
$36-40$ & 17 & 6.1 \\
Before pregnancy folic acid supplementation status & \\
Taken & 37 & 20.7 \\
Not Taken & 28 & 45.1 \\
Does not Remember & 21 & 34.1 \\
During pregnancy folic acid supplementation status & \\
Taken & 29 & 25.6 \\
Not Taken & 32 & 35.4 \\
Does not Remember & & 39.0 \\
Smoking during pregnancy & 3 & \\
Used & 79 & 3.7 \\
Not Used & & 96.3 \\
Late, force or vacuum birth & 16 & \\
Experience & 66 & 80.5 \\
Not experience & &
\end{tabular}

When gestational ages of mothers within the study were asked, it was determined that $46.3 \%$ of them were between 18 and $25,32.9 \%$ of them were between $26-30,14.6 \%$ of them were between 31-35 and $6.1 \%$ were between $36-40$ (Table 1). Due to inequalities in food consumption, education, health and other social benefits, problems of both developed and developing countries coexist in our country. Effect of social inequalities on nutrition begins in prenatal period. Brain, the most important organ of man, develops in the mother's womb in 2-3 years following birth. The main nutrients affecting brain development in the prenatal period are iodine, iron, zinc, folic acid, B12, B6, E and A vitamins and essential fatty acids. The fact that women do not get enough of these food items before and during pregnancy increases the risk of having a child with brain impairment (Baysal, 1997). In the study, when the parents of children with moderate and severe intellectual disability were asked "did you take folic acid supplementation before and during pregnancy?" few women stated that they received $(20.7 \%, 25.6 \%$ respectively), while others stated that they did not take or did not remember whether they took or not. A considerable number of women (96.3\%) did not smoke during pregnancy (Table 1).

In Özgüven's study (2015), it was stated that the proportion of children who know the reason why they are different is $16.9 \%$, and $82.5 \%$ are because of difficult birth or birth without oxygen rising from other reasons. According to Turkish Statistical Institute (TUIK)(2010) data, the rate of those with intellectual disability due to the problems experienced during childbirth is $16.3 \%$. In this study, it was found that $19.5 \%$ of the mothers' experience late, force or vacuum birth.

\section{Findings Related to Childrens 'Identification Characteristics}

$73.2 \%$ of the participants were male and $26.8 \%$ were female. Age of the children ranged from 5 to 18 , with an average of $10.71 \pm 0.52$ years. $39.0 \%$ of the children were second child of the family, $31.7 \%$ were the first, $17.1 \%$ were the third, $7.3 \%$ were the fourth and $4.9 \%$ were the fifth. Considering birth weight of the children $42.7 \%$ of them were born between 3001 and 3500 grams. Cognitive development in children is influenced by genetic and environmental factors. It has been determined that the potential of cognitive development in children is genetic, but adequate nutrition and rich stimuli has positive effects on cognitive development. Every year in the world, 1.4 million babies are born with a severe illness that will cause life-long negative consequences for the development of the nervous system. The causes of these diseases are largely unknown. However, due to the low birth weight, it is important to find a link 
between intelligence, visual impairment, cerebral palsy, retinopathy, blindness and autism. The incidence of these diseases is $0.6-0.8 \%$ in infants weighing between 3.5-4.5 kilograms, while it is $20.0 \%$ in infants whose birth weight is less than 1.5 kilograms. Although they seem different diseases, their common point is that they occur in the development stage of the brain. The most important responsibility for the development of the fetus brain belongs to the mother because, about $70.0 \%$ of brain cell divisions is completed before birth. Embryo's feeding depends entirely on the health and nutrition of the mother since the placenta is not developed yet at this stage (Demircioğlu and Yabanc1, 2003).

Breast milk affects brain development due to both content and effect of breastfeeding experience. Breast milk contains nutrients, growth factors, and hormones that increase brain development and at the same time it promotes cognitive and socio-emotional development of the baby by providing mother-infant interaction (Noğay, 2012). Since breast milk is rich of polyunsaturated fatty acids, it affects brain development, myelinization, retinal functions, and cell proliferation of infants. It is also important for the development of the baby's brain because it contains enough essential fatty acids (Samur, 2008). With the superiority of the quantity and especially the bioavailability of the vitamins, minerals, proteins, carbohydrates and lipids it contains, breast milk is a wonderful food which can meet all the requirements of infants alone for the first six months (Çınar et al., 2012). It is observed that psychomotor development and academic achievement of babies whose breastfeeding duration is 6 months or more are better than the ones whose breastfeeding time is 6 months and less (Oddy, 2011). In the study, it was determined that $12.2 \%$ of the children did not take any breast milk while $40.22 \%$ of the children took 13 months and more, $25.6 \%$ of the children received breast milk for the first 6 months and $22.0 \%$ of the children between 7-12 months. Evaluating the frequency of children's illnesses, it is seen that nearly half of them (43.9\%) frequently, $37.8 \%$ of the children once a month, and $18.3 \%$ of them get sick 2-3 times in a year. Individuals with intellectual disabilities experience more health problems than individuals without inadequacy. However, they do not need too much medical care except for those with severe and very severe intellectual disabilities. The physical appearance and health status of children with intellectual disabilities vary according to the degree of disability. The appearance and motor skills of children with mild intellectual disabilities are generally not different from their peers. This may be slightly different in children with moderate / severe intellectual disabilities. There are distinctive features such as ear, head, eye, and finger structure and weakness of muscles. Children with intellectual disabilities become more often ill than their peers. They do not know how to protect themselves as normal children do (Yllmaz, 2011).

\section{Findings About Nutrition Habits of Children}

In the study, $46.3 \%$ of mothers $(n=38)$ stated that they can eat their own meal when they were asked "how does your child consume their meals?", $46.3 \%$ of them $(n=38)$ pointed that they sometimes eat with support of someone else, $7.4 \%$ of them $(n=6)$ stressed that they eat sometimes themselves and sometimes with the support of others. Mothers of 44 children who were unable to feed themselves stated that they can't reach the independent nutrition stage. $39.1 \%$ of them told that they polluted the environment, $37.0 \%$ indicated that they cannot keep the spoon, and $23.9 \%$ complained that it took too much time for them. In a study in which eating habits of 117 intellectual disability children in a public school where 7-18 age group children with disabilities continue were compared to nondisabled ones, conducted by Mathur et al. (2007) in India, it is noticed that $60 \%$ of intellectually disability children cannot eat themselves. In a study conducted by İspiroğlu et al. (2012) to evaluate malnutrition, anemia and relatediron, folicacidand vitamin B12 deficiency in children who can not eat on their own due to neurological disease, it is stated that their feeding is dependent on mothers since $96 \%$ of them have severe intellectual disability and nutrition of them is really a serious problem. In his study, Özgüven (2015) stated that $27.4 \%$ of children can not eat on 
their own. Factors that make food intake difficult for children with disabilities; difficulty in food chewing, difficulty in swallowing food, eating back and sequeezing teeth, hard chewing, constipation due to continuous intake of water, not being able to eat food on his own, insufficiency in feeding and food consumption. Nutritional support is needed because of these problems (Köksal, 2012).

In the study, more than half of the children $(58.5 \%)$ eat their meals at the meal table, $23.9 \%$ in front of the TV, $8.5 \%$ eat when they are looked after and $3,7 \%$ eat while playing game. In a study conducted on autistic children, it was determined that $68.8 \%$ of the children eat at table, $18.7 \%$ eat while roaming, $10.0 \%$ eat at the floor table and 2.5\% eat standing (Girli et al., 2016) and results of study were similar. According to the results of the study, $62.2 \%$ of the children and adolescents select meals and $37.8 \%$ of them do not. Klein and Nowak (1999) found that $53 \%$ of the participants were reported to be reluctant to try new foods. Whiteley et al. (2000) found that eighty-three percent (83\%) of parents reported that their child ate a restricted repertoire of foods as their corediet. In an other study, individuals with autism spectrum disorder (ASD) and intellectual disability (ID) engaged in more food refusal behaviors (i.e., problem behavior increasing during mealtime, pushes food away, orattempttoleave area) than those with ID only. Inaddition, these individuals were found to have more food selectivity (i.e., food type) which has proven to be a diagnostic criterion for ASD (Matson 2007); however, the overall selectivity subscale was not significantly different between groups. Both diagnostic groups (ASD and ID or ID only) evinced feeding and meal time difficulties. Individuals with ASD and ID, on average, exhibited more feeding difficulties than those with ID only, which is consistent with research showing that ASD and ID in combination evince more problem behaviors which have, at least with children with ASD and ID, been provento be more treatment resistant than ASD alone (Ben-Itzchak and Zachor 2007). It is a study determined that participants in this study were 60 adults with ASD and ID (group 1) or ID only (group 2). Individuals with ASD and ID evinced more behaviorally-based feeding problems, such as food selectivity and refusal related difficulties relative to their peers with ID alone as assessed with the Screening Tool of feeding Problems (STEP). Those with ID only had more feeding skill difficulties than persons with ASD and ID. Overall, the ASD and ID group evinced more, and more severe feeding and meal time problems (Fodstad and Matson, 2008). EngelYeger et al, (2016), found that significant correlations between sensory processing disorders and eating problems were found in each intellectual disability level ( $\mathrm{r} 1 / 4.40, \mathrm{p} 4.05$ to $\mathrm{r} 1 / 4$ .57, p 4 .001), but most correlations were found among children with moderate and severe/profound level. Energy level significantly predicted aspiration frequency; smell/taste sensitivity significantly predicted food selectivity and food refusal frequency (Engel-Yeger et al., 2016).

Majority of children (91.5\%) consume 3 meals a day. $82.9 \%$ of the children consumed snacks and $41.2 \%$ of those who consumed snacks consumed twice a day. It is seen that $45.1 \%$ of the children and adolescents in the study are in favor of all meals, because most of them consume 3 meals a day. One of the issues that should be emphasized about eating habits is the concept of meal. Meals are a concept of daily consumption times. They are divided into two groups as main and snacks. The main meals are breakfast, lunch and dinner, while the refreshments are mid-morning, afternoon and night. While some people only consume at main meals, some people can consume some or all of the main meals and refreshments (Işkın and Sarışık, 2017). The most appropriate diet is to consume foods in six main meals, three main meals and three refreshments (Baban, 2010) and the most important point is to distribute the nutrients to be taken daily in three meals in a balanced manner (Baysal, 2006). There are evidences that healthy nutritional pattern behavior is associated with high academic achievement in children. Children who regularly eat 3 meals have higher academic achievement (Ogunsile et al., 2012; Kim et al., 2016). In a study conducted by Turgut and his colleagues on handicapped individuals (2014), it is found that 81 of the participants $(66.4 \%)$ ate three meals a day, $68(55.7 \%)$ skipped lunches and 47 $(38.5 \%)$ said that they do not find time for every meal. As much as the number of meals, content of 
the meal also affects academic achievement. Sufficient and various feeding, sufficient fruit and vegetable, micronutrient (protein, folate, iron, B vitamins, omega 3 , polyunsaturated fatty acids) and fish consumption were associated with better academic outcomes; it has been reported that IQ and memory ability is better in children who consume more fruits, vegetables and home-cooked meals. However, excessive consumption of lowquality foods in children (for example, sugary foods, salty snacks, fast-foods); unhealthy nutrition patterns such as inadequate consumption of dairy products and high nutritional value foods (vegetables, fruits, meat, fish, eggs) were found to be associated with negative overall performance (Meydanlıoğlu, 2016). When mothers are asked how they evaluate their childrens 'appetite, half of the mothers $(51.2 \%)$ respond normally. According to the results of a study to determine the nutritional status of intellectually disabled children and adolescents, $6.6 \%$ of the children eat lunch at institutions, $73.8 \%$ frequently, $21.2 \%$ occasionally eat refreshments. When parents were asked about the problems they experienced while eating, in the same study, it was stated that $44.4 \%$ of the children chose to eat, $33.2 \%$ refused to eat, and $24.9 \%$ showed aggressive behaviors during meals. It is determined that $10.0 \%$ of children can swallow nutrients in liquid or mash style. While
$91.7 \%$ of the children frequently stated that they were hungry, $19.1 \%$ of them did not express that they are full. According to the parents' evaluation, $18.3 \%$ of the children eat less than usual and $14.5 \%$ eat more than usual (Özgüven, 2015).

When mothers are asked "how do you evaluate your child's development", more than half (58.5\%) gave the answer "normal". It is also observed that $39.0 \%$ of the children in the study take regularly vitamins or minerals. In a recent study to examine nutritional intake between children with ASD and typically developing children, Herndon et al. (2009) used a 3-day diet record and found that a large number of both children with ASDs and typically developing children consumed less than the recommended dietary intakes for several nutrients, including calcium, iron, vitamins D and E, and fiber. Children with ASDs were also found to have higher intakes of vitamins B-6 and E and lower intakes of calcium than typically developing children (Herndon et al., 2009).Nutrition supportmay be needed in the form of vitamin and mineral supplementation. The dietiti anorother nutrition professional can also suggest waystoen rich the diet sothat every bite contributes to nutritional adequacy in the child's diet. While working on increasing the acceptable foods, nutrition counseling is critical (Cermak et al, 2010).

Table 2. Distribution of children according to their nutrition habits.

\begin{tabular}{|c|c|c|c|c|c|c|c|c|c|c|c|c|c|c|}
\hline & \multicolumn{2}{|c|}{ Everyday } & \multicolumn{2}{|c|}{ Every other day } & \multicolumn{2}{|c|}{ Once a week } & \multicolumn{2}{|c|}{$\begin{array}{l}\text { Once in every } 15 \\
\text { days }\end{array}$} & \multicolumn{2}{|c|}{ Once in a month } & \multicolumn{2}{|c|}{ Never } & \multirow[t]{2}{*}{$\mathrm{TP}$} & \multirow[t]{2}{*}{ YTP } \\
\hline & $\mathrm{n}$ & $\%$ & $\mathrm{n}$ & $\%$ & $\mathrm{~N}$ & $\%$ & $\mathrm{n}$ & $\%$ & $\mathrm{n}$ & $\%$ & $\mathrm{n}$ & $\%$ & & \\
\hline $\begin{array}{l}\text { Milk, yogurt and } \\
\text { ayran }\end{array}$ & 48 & 58.5 & 14 & 17.1 & 14 & 17.1 & 4 & 4.9 & 0 & 0 & 2 & 2.4 & 346 & 84.39 \\
\hline Cheese & 44 & 53.7 & 11 & 13.4 & 15 & 18.3 & 0 & 0 & 2 & 2.4 & 10 & 12.2 & 319 & 77.80 \\
\hline Egg & 36 & 43.9 & 18 & 22.0 & 20 & 24.4 & 1 & 1.2 & 0 & 0 & 7 & 8.5 & 314 & 76.59 \\
\hline Honey, pekmez, Jam & 23 & 28.0 & 12 & 14.6 & 22 & 26.8 & 1 & 1.2 & 5 & 6.1 & 19 & 23.2 & 236 & 57.56 \\
\hline Redmeat & 9 & 11.0 & 5 & 6.1 & 39 & 47.6 & 14 & 17.1 & 10 & 12.2 & 5 & 6.1 & 220 & 53.66 \\
\hline Fish meat & 1 & 1.2 & 1 & 1.2 & 30 & 36.6 & 20 & 24.4 & 14 & 17.1 & 16 & 19.5 & 153 & 37.32 \\
\hline Chicken meat & 6 & 7.3 & 6 & 7.3 & 43 & 52.4 & 13 & 15.9 & 7 & 8.5 & 7 & 8.5 & 226 & 55.12 \\
\hline Legume & 4 & 4.9 & 12 & 14.6 & 45 & 54.9 & 12 & 14.6 & 1 & 1.2 & 8 & 9.8 & 228 & 55.61 \\
\hline Vegetable & 17 & 20.7 & 13 & 15.9 & 28 & 34.1 & 9 & 11.0 & 5 & 6.1 & 10 & 12.2 & 244 & 59.51 \\
\hline Fruit & 60 & 73.2 & 12 & 14.6 & 7 & 8.5 & 0 & 0 & 0 & 0 & 3 & 3.7 & 369 & 90.00 \\
\hline Cereals & 11 & 13.4 & 11 & 13.4 & 31 & 37.8 & 16 & 19.5 & 6 & 7.3 & 7 & 8.5 & 230 & 56.10 \\
\hline Soup & 34 & 41.5 & 26 & 31.7 & 15 & 18.3 & 2 & 2.4 & 1 & 1.2 & 4 & 4.9 & 324 & 79.02 \\
\hline Salad & 34 & 41.5 & 16 & 19.5 & 18 & 22.0 & 2 & 2.4 & 2 & 2.4 & 10 & 12.2 & 294 & 71.71 \\
\hline $\begin{array}{l}\text { Bologna, salami, } \\
\text { sausages }\end{array}$ & 13 & 15.9 & 9 & 11.0 & 34 & 41.5 & 10 & 12.2 & 4 & 4.9 & 12 & 14.6 & 227 & 55.37 \\
\hline Prepared Fruit Juice & 31 & 37.8 & 10 & 12.2 & 20 & 24.4 & 5 & 6.1 & 3 & 3.7 & 13 & 15.9 & 268 & 65.37 \\
\hline Fizzy drinks & 3 & 3.7 & 5 & 6.1 & 15 & 18.3 & 19 & 23.2 & 7 & 8.5 & 33 & 40.2 & 125 & 30.49 \\
\hline Fries & 13 & 15.9 & 9 & 11.0 & 35 & 42.7 & 14 & 17.1 & 4 & 4.9 & 7 & 8.5 & 238 & 58.05 \\
\hline Tea & 39 & 47.6 & 9 & 11.0 & 9 & 11.0 & 2 & 2.4 & 1 & 1.2 & 22 & 26.8 & 263 & 64.15 \\
\hline Chocolate, sweets & 22 & 26.8 & 15 & 18.3 & 28 & 34.1 & 7 & 8.5 & 4 & 4.9 & 6 & 7.3 & 272 & 66.34 \\
\hline
\end{tabular}


When the mothers were asked the question "are you satisfied with the nutrition of your children before they start education", $59.8 \%$ said yes, $40.2 \%$ said no. More than half of them (59.8\%) indicated that there were positive changes in their children's eating habits after they started school. $53.7 \%$ of the mothers responded "yes" when they were asked "Do you think your child has nutrition problems?" $25.0 \%$ of the mothers who thought that their child has a nutrition problem stated that their children eat too much, $25.0 \%$ of them had said that they eat only few meals, $18.2 \%$ pointed that they were reluctant to eat, $15.9 \%$ told that they were slow to nourish and \% 15.9 stated that they could not chew the food. In literature it is stated that eating disorders are seen among the handicapped individuals such as malnutrition, obesity, chewing and swallowing difficulty, dental problems, gastroesophageal reflux, pica problem (eating and requesting chalk, soil), eating secret food, wanting to eat excessively, eating and distributing food (Marshall et al 2003, Hakverdioğlu 2006). Similar problems have been identified in a study conducted in India (Mathur et al., 2007); 23.9\% of children with intellectual disabilities are choosy in eating, $82.9 \%$ do not consume solid food, $1.7 \%$ could not express their hunger, and $9.4 \%$ cannot say that they are full.

It was determined in the Girli and his colleagues study (2016) that (37.8\%) mothers had more than one problem during feeding. In the study, When the mothers were asked the question "Do your children know which foods are healthier for them?" $75 \%$ of them stated that their children are now aware which food is healthy for them. Even though children $(64.7 \%)$ do not like some foods, they sometimes consume since they are healthy.

Percentage of consumptions consumed by children according to their daily consumption is as follows: fruit 90.00 (369 points), milk, yoghurt and ayran 84.39 (346 points), soups 79.02 (324 points), cheese 77.80 (319 point), egg 76.59 (314 points) and salad 71.71 (294 points) (Table 2). As seen in Table 2 , yoghurt and ayran (58.5\%), cheese (53.7\%), tea $(47.6 \%)$, egg $(43.9 \%)$, soup $(41.5 \%)$ and salad $(41.5 \%)$ were eaten every day by the children and adolescents, legume $54.7 \%$, chicken meat $(52.4 \%)$, red meat $(47.6 \%)$, fried food $(42.7 \%)$ and bologna, salami and sausage (40.2\%) were consumed once a week, and they did not consume fizzy drinks $(42.5 \%)$ at all. It was determined that $40.4 \%$ of the students prefer to use tea as a drink every day. When tea is consumed during meals, iron in the digestive tract combines with polyphenols or tannins in the tea to form a complex that does not dissolve, thus it reduced iron absorption. It is recommended that tea should not be consumed during and after meals especially when consuming animal nutrients (Işıksoluğu, 2001), but $47.6 \%$ of the participants drink tea every day (Table 2).

In every part of life, it is necessary to be healthy physically and mentally and to maintain health with enough and balanced nutrition (Baysal, 2007). Adequate and balanced nutrition is perhaps one of the basic conditions and maybe the most important for healthy life of individuals and societies, economic and social development of the world, and promotion of welfare (Turan et al., 2009). Eating habits acquired during childhood and adolescence periods, the most important periods in which habits are acquired and settled, are carried to adulthood and can be transformed into lifelong behaviors. Incorrect eating habits such as inadequate and unbalanced nutrition, skipping meals, one-sided nutrition, frequent and excessive consumption of fast food, and eating behavior disorders affect the health of children and adolescents negatively (Gümüş et al., 2015). Family has great responsibilities to maintain a healthy life. It should also be well known that more attention needs to be given to the nutritional levels of our disabled children with limited activity space because as parents and individuals, it is everyone's duty not to allow health barrier to become another obstacle for them. It is necessary that they should be feed more carefully and they should consume foods that are high in nutritional value (Turgut et al., 2014). Milk and its products (yoghurt, cheese, etc.) are the nutrient groups to be consumed in terms of being the main source of vitamins, minerals, carbohydrates and especially calcium due to the amount of protein and quality for individuals in preadolescent-adolescence period and other age groups which are growth and development periods (Önay, 2002). In this study, daily consumption of milk, yoghurt and ayran was determined as $58.5 \%$ (Table 2 ). In the other study 
on children with autism (2016), it was determined that $6.1 \%$ of children do not consume milk and dairy products, $8.4 \%$ meat products, $13.6 \%$ egg, $12.2 \%$ legume, $12.2 \%$ vegetables, $4.9 \%$ fruit, $3.7 \%$ bread cereal group and $6 \%$ do not consume butter. In the same study, milk and dairy products are the most consumed foods (85.4\%). Some of the basic food groups such as eggs, meat, vegetables, fruit, legume are not consumed by children every day (Girli et al., 2016). Inadequate and low quality nutrition in children can disrupt rapidly developing brain and cognitive functions and affect the academic achievement of children. Sufficient and various nutrition, sufficient fruit and vegetable, micronutrient (protein, folate, iron, B vitamins, omega 3, polyunsaturated fatty acids) and fish consumption are associated with better academic outcomes; it has been reported that IQ and memory ability are better in children who consume more fruits, vegetables and home-made meals. However, excessive consumption of lowquality foods in children (for example, sugary foods, salty snacks, fast-food foods); unhealthy nutrition patterns such as inadequate consumption of dairy products and high nutritional value foods (eg vegetables, fruits, meat, fish, eggs) were found to be associated with negative overall performance (Meydanloglu, 2016).In our study, it is determined that percentage of chocolate and sweets consumptions consumed by children is 66.34 (272 points) (Table 2). In intellectual disability children, particularly sugary food consumption can lead to inability to meet the elements required for healthy growth and development, and to excessive weakness or obesity (Özbaş et al., 2018).

It is recommended to consume 4-5 portions of vegetables and fruits a day for adequately and balanced diet (Duyff, 2003). In this study, it was determined that more than half of the students consumed fresh fruits and vegetables every day (73.2\%, 20.7\% respectively) (Table 2). One of the easiest ways to consume fruit is to consume it as fruit juice (Pisoschi et al, 2009). In the study, it is good that most of the children $(73.2 \%)$ consume fruit every day and ready fruit juice consumption is $37.8 \%$. Noğay (2013) found that folic acid and calcium intake in children with intellectual disability is below the recommended value.
Özgüven (2015) indicated in his study that, according to the information given by the parents of the children participated in the study, $81.3 \%$ of the children eat eggs and fruit willingly and $77.2 \%$ of the children eat sugary foods. In the same study, $22.0 \%$ of the foods that children refuse to eat are cheese, followed by vegetables with $17.8 \%$. In a conducted study, it is determined that $71.0 \%$ of the children do not consume bread daily, 58.1\% legume, $48.4 \%$ yoghurt, $45.2 \%$ egg, 35.5\% ayran, $32.3 \%$ milk and $48.4 \%$ crisps, $29.0 \%$ of lahmacun, pide, pizza, hamburger and $22.62 \%$ of them do not consume fizzy drinks (Kaleli et al., 2017).

\section{Findings About the Behaviors of Mothers Towards Their Children's Nutrition}

Majority of mothers (92.7\%) allow children to eat whatever they want. A little more than half of the mothers $(53.7 \%)$ insisted that children eat food even if they are not hungry, and $81.7 \%$ of them allowed children to eat junk food when they want. In their study, Kaleli et al. (2017) found that 45.2\% of mothers said yes, $54.8 \%$ said no when they were asked "Do you allow your child to eat whenever they want? In our study $70.7 \%$ of mothers try to limit amount of food that child would eat in the next meal when they find that their children eat more than usual. Other studies also show that parents have control over their children's eating habits by restricting food access, increasing the pressure on eating, or keeping a close eye to their nutrition type (Birch and Davison, 2001, Birc, 2006). Özbaş et al., (2018) found that $43.8 \%$ of the children had problems with nutrition, and $28.1 \%$ of the children had missed their meal. $90.6 \%$ of the children consumed snacksexcept in their main meals, and children received $1004 \pm 435 \mathrm{kcal}$ more energy than the average energy needed perday. Nearly half of the mothers $(43.9 \%)$ said that they try to make them eat again when they were asked "what do you do when your child does not finish eating the food on the table", $28.8 \%$ said that they remove the food, $18.3 \%$ told that if children eat the food they are given, they reward them and 9.8\% responded that they recommend another type of food. It was determined that mothers use various reward methods. For instance, $53.3 \%$ of the 
mothers use take them out, $33.3 \%$ give sugar, chocolate, chips and $13.4 \%$ do what they want. In an another study, it was seen that $40.7 \%$ of the families use food to attract the attention of the child to another direction and $65.8 \%$ use food to reward the child (Girli et al., 2016)." In their study, Kaleli et al. (2017) found that $41.9 \%$ said yes, $54.8 \%$ said no when they were asked "Do you prepare food when your child is hungry?", $32.3 \%$ answered yes, $67.7 \%$ answered no when they were asked "Does your child have dinner regularly every day?", and $3.2 \%$ answered yes, $96.8 \%$ answered no when they were asked "Do you need to learn about healthy nutrition?".

\section{Results}

Age of mothers' of 82 children with moderate and severe intellectual disability within the study were 35 or older $(65.9 \%)$. It was determined that more than half $(59.8 \%)$ of the children's mothers were primary school graduates. Majority $(91.4 \%)$ of the mothers are housewives. $81.7 \%$ of the children have a nuclear family. $73.2 \%$ of the children were male and $26.8 \%$ were female. Age of the children ranged from 4 to 18 , with an average of $10.71 \pm 0.52$ years. In the study, $46.3 \%$ of mothers stated that they can eat their own meal when they were asked "how does your child consume their meals?", $46.3 \%$ of them pointed that they sometimes eat with support of someone else, $7.4 \%$ stressed that they eat sometimes themselves and sometimes with the support of others. Mothers of 44 children who were unable to feed themselves stated that they can't reach the independent nutrition stage. $39.1 \%$ of them told that they polluted the environment, $37.0 \%$ indicated that they cannot keep the spoon, and $23.9 \%$ complained that it took too much time for them. This study, majority of mothers $(92.7 \%)$ allows children to eat whatever they want. A little more than half of the mothers $(53.7 \%)$ insisted that children eat food even if they are not hungry, and $81.7 \%$ of them allowed children to eat junk food when they want. It is also observed that $39.0 \%$ of the children in the study take regularly vitamins or minerals. There are evidences that healthy eating pattern behavior is related with high academic achievement in children. Children who eat regularly 3 meals are more likely to have academic achievement, and it is observed in the study that the vast majority of children consume 3 meals a day. Percentage of consumption of food and drink consumed by children and adolescents, according to their daily consumption were found as; fruit 90.00, milk, yoghurt and ayran 84.39 , soups 79.02 , cheese 77.80 , egg 76.59, salad 71.71. In the light of these results, it was determined that 3 meals especially in children and adolescents, regular and highquality meal consumption habit and sufficient micro nutrients, vegetables, fruits, milk and fish consumption, has a positive effect on cognitive performance and school success. Therefore, family, parents, teachers, schools and society have important tasks especially for the consumption of food items that support the development of children's cognitive functions, including gestation and early childhood. Some research has shown that the appearance and motor skills of children with mild intellectual disabilities do not differ significantly from their peers who normal development, and that there are significant differences in children with severe and moderate intellectual disabilities. Although this is the case for the general physicalappearance, children with intellectual disabilities are known to be at a lower level than the children with normal development dueto the few movements and manyother factors in terms of physical fitness parameters. And this is a common point that research in this field is combined (İlhan \& Esentürk, 2015). Children with moderate disability in these groups are often noticed in the pre-school period. Physical disability and problem behaviors are more common than those with mildly inadequate disabilities. Academic studies are usually limited to reading skills and teaching of basic concepts. Individuals with severe disability are often noticed at birth or immediately after birth. There are significant damages in their central nervous system. They have difficulty in meeting many personal needs and they need adult support. Their training focuses on communication skills and selfcare skills such as toilet, dressing, eating and drinking (Ataman, 2003).Also, studies show that children of intellectual disability are more disadvantaged over weight, obesity, diet, eating, drinking and inactive life style compared to 
children who normal development (Curtin et al., 2005; Curtin et al., 2010). In order to place adequate and balanced eating habits, it is necessary for children to acquire eating skills first. Children with intellectual disabilities are more likely to develop eating habits later than children with normal development. Factors that affect the ability of children with intellectual disabilities to give them eating abilities can be physical, sensory, behavioral, and environmental. Deficiencies in the development of small muscle skills, inadequacies in the nervous system, and disorders of the mouth and muscle structures (rabbit lip, half-palate, etc.) and situations requiring dieting can lead not gaining or late gaining of eating skills. Inefficiencies in sight or hearing and inadequate learning environments can adversely affect the acquisition of eating habits. At the same time, some behavioral problems related with eating such as refusing food and withdrawing may negatively impact eating behavior (Varol, 2004). In this context, it will be useful for the people who are responsible for the nutrition of the inadequate individuals to be aware of nutritional problems and possible causes, to be informed about the measures that must be taken to eliminate these problems. Inadequate individuals who are highly dependent on their caregivers particularly those with moderate and severe disability are particularly affected by the dietary habits of their families. Family's eating habits, number of meals, features and quantities of foods they consume and attitudes and behaviors they exhibit towards their children in the feeding influence the nutritional characteristics of their children. Parents should be educated about regular nutrition. They should be informed about the number of daily meals, amount of portions to be consumed at meals and benefits of the foods given, and also they get children gain habit of having regular breakfast. Parents should be trained about nutrition and its importance as well as their children's development. It is also believed that families should be supported by doctors, nurses and dietitians in Family Health Center to monitor their children's development. Inservice training of staff in Family Health Centers to understand intellectual disability and to provide more functional care and services will both ease the work of the staff and make the individual who are inadequate and his / her family take higher quality services. The nutritional statuses of intellectual disability children should be monitored closely, and sufficient nutritional support should be provided in order to ascertain a normal body weight, linear growth, and a higher quality of life.

As the child's intellectual disability leveled up; the physical, emotional, economic, social burden and time requirement of the family increased. The care, treatment and rehabilitation of a child with intellectual disability require more human strength, cost and time for a healthy child. The support of health and psychosocial professionals to care for children who are dependent on self-care needs and who have special education or have severe intellectual disability is of utmost importance both for mother and family health. Training on intellectual disability children and family care and coping requires a multidisciplinary approach (Turan Gürhopur and İşler Dalgıç, 2017). Systematic and effective identification of feeding problems and problematic meal time behaviors is essential in order to inform the physicians and therapists who can be involved with evaluation and treatment (Matson, 1997). Also it is crucial for fammilies to solve nutrition porblems, have healthy nutrition habits and adopt suitable nutrition methods for their intellectually disabled childrens that they can lead a quality life. Nutritional disorders in intellectuallydisabled children do not only affect themselves, but the whole family is affected by the situation as well and leads to stress in family members. Healthy nutrition is important for the quality of life of intellectually disabled people and their families as much as fornormally developed children and their families. However, there are few empirically valid studies on nutrition disorders and their solutions. It is very necessary to present scientific based solutions to deal with nutrition disorders for intellectually disabled children, families, educators, experts and related service providers (Meral, 2017). When there is a problem of eating, check whether there is any genetic condition before starting the treatment studies and if there is not eating habits should be emphasized. When habits 
are the subject, the most important factor is the family. The processes of care, choice of food, preparation and feeding, amount and frequency of meals, preference of foods in meals carried out by the families apart from the attainment of nutritional habits in children with moderate and severe disability show us how important knowledge level of families in the nutritional status of the individual is. In addition, when it is thought that many of the problems that can be experienced in addition to the inadequacy, which can be achieved by using the existing capacities of the individuals at the highest level with the placement of healthy eating habits, we think that the duties and responsibilities of the families of those with moderate and severe disability will be more. In this regard, family education is importand. During the education; It will be useful to focus on gains such as nutritional problems and their possible causes, solution suggestions for the reduce of the problems, determining the nutritional goals suitable fort he rate and degree of disability of children, effective reinforcement in gaining the right nutrition habits, in order for children to develop their independent nutrition skills.

\section{References}

AbdAllah, A.M., El-Sherbeny, S.S.A., \& Khairy S.(2007). Nutritionalstatus of mentally disabled children in Egypt. Egyptian J Hospital Med, 29, 604-615.

Adachi-Mejia, A.M., Longacre, M.R., Gibson, J.J., Beach, M.L,.Titus-Ernstoff, L.T., \& Dalton, M.A. (2007). Children with a tv in their bedroom at higher risk for being overweight. International Journal of Obesity, 31(4), 644.doi: $\underline{10.1038 / \text { sj.ijo. } 0803455}$

Ali, Z. (2001). Pica in people with intellectual disability: A literature review of aetiology, epidemiology and complications. Journal of Intellectual and Developmental Disability, 26(3), 205-215.

Aktaş, N. (1979). Hollanda'daki Türk işçi ailelerinin beslenme alışkanlıklarını etkileyen faktörler üzerine bir araştırma. Ankara University Faculty of Agriculture Faculty of Home Economics, Ankara.
American Psychiatric Association. (2013). Diagnostic and statistical manual of mental disorders (DSM5) (5th ed.). Arlington, VA: American Psychiatric Publishing.

Ataman, A., Eripek, S., Konrot, A., Sarı, H., \& Sucuoğlu, B. (2003). Özel gereksinimli çocuklar ve özel eğitim. Ankara: Gündüz Education and Publishing.

Aykut, M. (2011). Toplum beslenmesinin önemi. General Information Book. (Ed) Öztürk Y. Günay O. Kayseri: Erciyes Üniversity Publications.

Baban, M. (2010). Obez ve diyabetik yetişkinlerin beslenme bilgi düzeyleri, beslenme alı̧kanlıkları, diyet ve diyabetik ürünleri algzlama düzeylerinin karşılaştırmalı olarak değerlendirilmesi. İstanbul Üniversitesi, İstanbul.

Baysal, A. (1997). Bilişsel yeteneğin gelişiminde beslenmenin rolü. Beslenme ve Diyet Dergisi, 26(1), 1-4.

Baysal, A. (2006). Beslenme. Ankara: Şahin Yayıncılık. Baysal, A. (2007). Beslenme. Ankara: Şahin Yayıncllık.

Ben-Itzchak, E., \& Zachor, D. A. (2007). The effects of intellectual functioning and autism severity on the outcome of early behavioral interventions for children with autism. Research in Developmental Disabilities, 28, 287303. doi:10.1016/j.ridd.2006.03.002

Bertoli, S., Battezzati, A., Merati, G., Margonato, V., \& Maggioni, M. (2006). Nutritional status and dietary patterns in disabled people. Nutr Metab Cardiovas Dis., 16(2), 100-112, doi:10.1016/j.numecd.2005.05.007

Birch, L.L., \& Davison, K.K. (2001). Family environmental factor sinfluencing the developing behavioral controls of food intake and childhood over weight. Pediatrics Clinics of North America, 48(4), 893-907.

Birch, L.L. (2006). Child feding practices and the etiology of obesity. Obesity, 14(3), 343-344.

Casey, VA., Dwyer, JT., Colemen, KA., \& Valadian I. (1992). Body mass index from childhood to midddle age: A 50-y follow up.Am J ClinNutr, 56, 14-18.doi:10.1093/ajen/56.1.14

Cermak, S. A., Curtin, C., \& Bandini, L. G. (2010). Food selectivity and sensory sensitivity in children with autism spectrum disorders. American Dietetic Association, 110(2), 238246.Doi:10.1016/j.jada.2009.10.032

Curtin, C., Bandini, L.G., Perrin, E.C., Tybor, D.J. \& Must A. (2005). Prevalence of overweight in children and adolescents with attention 
deficithy per activitydisorder and autism spectrum disorders: a chart review. BMC Pediatric, 5(1), 48-56.doi: 10.1186/1471-2431-5$\underline{48}$

Curtin, C., Anderson, S. E., Must, A. \& Bandini, L. (2010). The prevalence of obesity in children with children: A secondary data analysis using nationally representative data from the National Survey of Children's Health. BMC Pediatrics, 10(11), 24-31.doi: 10.1186/14712431-10-11.

Çınar, N., Köse, D., \& Doğu, Ö. (2012). Nutrition with multiple babies breastmilk. Sakarya Medical Journal, 2(3),115-21.doi: 10.5505/sakaryamj.2012.20082

Demircioğlu,Y., \& Yabanc1, N. (2003). Beslenmenin bilişsel gelişim ve fonksiyonları ile ilişkisi. Hacettepe University Journal of Education, 24, 170-179.

Demirel, F., Üner, A., \& Kırımi, E. (2001). Van ili kırsalındaki annelerin çocuk beslenmesindeki alışkanlıkları ve uygulamaları. Van Medical Journal, 8(1), 18-21.

Duyff, R.L. (2003). The American Dietetic Association's complete food and nutrition guide. (Translation Ed: Sevinç Yücecan, Gülden Pekcan, Berat Nursal, Tanju Besler). İstanbul: Acar Yayıncllık, $614 \mathrm{~s}$.

Eker, H.H., Taşdemir, M., Mercan, S., Mucaz, M., Bektemur, G., Şahinöz, S., \& Özkaya, E. (2018). Obesity in adolescents and the risk factors. Turk J Phys Med Rehab, 64(1), 37-45, doi: 10.5606/tftrd.2018.1402

Engel-Yeger, B., Hardal-Nasser, R., \& Gal, Eynat. (2016). The relationship between sensory processing disorders and eating problems among children with intellectual developmental deficits. British Journal of Occupational Therapy, 79(1), 17-25, doi: 10.1177/0308022615586418

Ergün, C. (2003). Sağlıklı Beslenme Kavramı ve tüketici algisı üzerine bir araştırma. Hacettepe University, Health Sciences Institute, Ankara.

Eripek, S. (1996). Zihinsel engelli çocuklar 2. Edition. Eskişehir: Anadolu University Publications. p.137-155.

Fodstad, C.J., \& Matson, J.L. (2008). A comparison of feeding and meal time problems in adults with intellectual disabilities with and without autism. J Dev Phys Disabil, 20, 541550, doi: 10.1007/s10882-008-9116-6

Gal, E., Hardal-Nasser, R., \& Engel-Yeger, B. (2011). The relationship between the severity of eating problems and intellectual developmental deficit level. Res Dev Disabil, 32, 1464-9.doi: 10.1016/j.ridd.2010.12.003.

Girli, A., Özgönenel, S.Ö., Sarı, H.Y., \& Ardahan, E. (2016). Otizmi olan çocukların beslenme durumunun değerlendirilmesi. Child and Civilization, 1, 87-99.

Gravestock, S. (2000). Eating disorders in adults with intellectual disability. Journal of Intellectual Disability Research, 44, 6, 625637.https://doi.org/10.1111/j.13652788.2000.00308.x

Gündüz, M., \& Akın, A. (2015). Türkiye'de devlet okullarındaki özel eğitimle ilgili sorunlar ve çözüm önerileri. Eğitim ve Öğretim Araştırmaları Dergisi, 4(2), 86-95.

Gümüş, D., Kızıl, M., Dikmen, D., \& Uyar, F. M. (2015). Gelir düzeyinin ilköğretim öğrencilerinin besin tercihlerine etkisinin değerlendirilmesi. Hacettepe University Faculty of Health Sciences Journal, 2(1), 1-15.

Hakverdioğlu, İ. (2006). İleri Derecede Mental Retardasyonlu Bireylerde malnütrisyon ve beslenme durumunun değerlendirilmesi. Hacettepe University, Health Sciences Institute, Ankara.

Haynos, A.F., \& O’Donohue, W.T. (2012). Universal childhood and adolescent obesity prevention programs: review and critical analysis. Clinical Psychology Review, 32(5), 383399.doi: 10.1016/j.cpr.2011.09.006

Herndon, A.C., Di Guiseppi, C., Johnson, S.L., Leiferman, J., \& Reynolds A. (2009). Does nutritional intake differ between children with autism spectrum disorders and children with typical development? J Autism Dev Disord, 39, 212-222.doi:10.1007/s10803-008$\underline{\text { 0606-2 }}$

Hinckson, E.A., Dickinson, A., Water, T., Sands, M., \& Penman, L. (2013). Physicalactivity, dietary habits and overall health in overweight and obese children and youth with intellectual disability or autism. Research in Developmental Disabilities 34, 1170-1178, https://doi.org/10.1016/j.ridd.2012.12.006 
Işıksoluğu, M.K. (2001). Beslenmede kahve, çay, flavonoidler ve sağlık. (1. Edition). Ankara: Damla Yayıncilik.

Işkın, M., \& Sarışık, M. (2017). Üniversite öğrencilerinin öğün atlama nedenlerinin belirlenmesi: Sakarya Üniversitesi örneği Journal of Recreation and Tourism Research, 4(special issue 1), 430-440.

İlhan, L.E., \& Esentürk, O. K. (2015). Zihinsel yetersizliği olan çocuklarla normal gelişim gösteren akranlarının bazı fiziksel uygunluk parametrelerinin incelenmesi. Gazi Beden Ĕ̆itimi ve Spor Bilimleri Dergisi, 20(1-4), 11-17.

İnandı, T., Savaş, N., Arslan, E., Yeniçeri, A., Peker, E., Alışkın, Ö., Erdem, M., \& Durmaz, E. (2016). Hatay'da akraba evliliği sıklığı, nedenleri, çocuk sağlığı, ilişkilerde mutluluk ve yaşam doyumu. Turk J Public Health, 14(1), 43-55. http://tjph.org/ojs/index.php/.

İspiroğlu, E., Güler, E., Dilber, C., Dalkıran, T., Olgar, Ş., Davutoğlu, M., \& Garipardıç, M. (2012). Nörolojik hastalık nedeniyle kendi başına beslenmeyen çocuklarda anemi, b12 vitamini, folik asit ve demir eksikliği. Türk Ped. Res, 47, 199203.https://dx.doi.org/10.4274/tpa.845

Jansen, D.E.M.C., Krol, B., Groothoff, J.W., \& et al. (2004). People with intellectual disability and their health problems: A review comparative studies. Journal of Intellectual Disability Research, 48, 93102.https://doi.org/10.1111/j.13652788.2004.00483.x

Kaleli, S. Kılıç, N. Balçin, D. Bingöllü, E. Aşıcı, N. (2017). Sakarya Özel Eğitim Kurumu'nda eğitim gören çocukların beslenme tarzında ebeveynlerin bilgi ve tutumlarının incelenmesi. Online Turkish Journal of Health Sciences, 2(2), 19-26.

Kapi, U. Bhavna, A. (2002). Adverse effects of poor micronutrient status during childhood and adolescence, Nutr Rev, 60, 84-90.

Karasar, N. (2011). Bilimsel araştırma yöntemi (22. Edition). Ankara: Nobel Publishing.

Kim, S.Y., Sim, S., Park, B,. Kong, I.G., Kim, J.H., \& Choi, H.G. (2016). Dietary habits areas sociated with school performance in adolescents. Medicine (Baltimore), 95(12), e3096.doi:10.1097/MD.0000000000003096

Klein, U., \& Nowak, A.J. (1999). Characteristics of patients with autistic disorder (AD) presenting for dental treatment: A survey and chart review. Spec Care Dentist, 19, 200207.

Köksal, E. (2007). Türkiye'de okul çağı çocuklarda beslenme, sağlık durumu ve uygulamalar. Verbal Bulletin. V. International Nutrition and Dietetic Congress, Ankara.

Köksal, E. (2008).Beslenme ve bilişsel gelişim Ankara: KlasmatYayıncilik.

Köksal, G. (2012). Engellilerde beslenme. Ankara: Ministry of Health Publications.

Kömerik, N., Kırzıoğlu, Z., \& Efeoğlu, G. (2012). Zihinsel engelli bireylerde ağ1z sağlığ1 The Journal of Dental Faculty of Atatürk Üniversitesi, 22, 96-104.

Köşgeroğlu, N., \& Mertboğa, S. (2011). Yaşam Aktivitelerine Dayalı Hemşirelik Modeli (YADHM)'ne göre zihinsel engelli bireylerin sorunları ve hemşirelik. Maltepe Üniversitesi Journal of Nursing Science and Art, 4, 149-152.

Maity, A., \& Gupta, K. (2010). Nutritional status of mentally retarded children and correlation between prenatal care and mental retardation. Indian J Maternal Child Health, 12(4),1-9.

Marshall, D. McConkey, \& Moore, R. G. (2003). Obesity in people with intellectual disability: the impact of nurseled health screenings and health promotion activities. Journal of Advanced Nursing, 41, 147153.https://doi.org/10.1046/j.13652648.2003.02522.x

Mathur, M., Bhargava, R., \& Benipal, R., et al. (2007). Dietary habits and nutritional status in mentally retarded children and adolescents: A studyfrom North Western India. I Indian Assoc Child Adolesc Ment Health, 3, 18-20.

Matson, J.L., \& Smiroldo, B.B. (1997). The validity of the mania subscale of the diagnostic assessment for the severely handicapped-ii (DASH-II). Research in DevelopmentalDisabilities, 18(3), 221-225.

Matson, J. L. (2007). Current status of differential diagnosis for children with autism spectrum disorders. Research in Developmental Disabilities, 28, 109-118. doi:10.1016/j.ridd.2005.07.005

Meral, B. F. (2017). Otizm spektrum bozukluğu olan çocuklarda beslenme problemleri ve bilimsel dayanaklı davranışsal müdahaleler. Ankara Üniversitesi Ĕ̆itim Bilimleri Fakültesi Özel 
Eğitim Dergisi. 18(3), 493-508. doi: 10.21565/ozelegitimdergisi.323301

Meydanlıŏlu, A. (2016). Çocukların besin tüketimi ve beslenme davranışlarının akademik başarılarına etkisi. Journal of Research in Education and Teaching, 5(4), 368-376.

Nicholls, D., Christie, D., Randall, L., \& Lask, B. (2001). Selectiveeating: symptom, disorder, or normal variant. Clin. Child Psychol.Psychiatry, 6, 257-270

Noğay, N.H. (2012). Beslenmenin beyin gelişimi üzerindeki etkisi. Journal of Vocational Colleges, December, 42-45.

Nogay, N.H. (2013). Nutritional status in mentally disabled children and adolescents: A study from Western Turkey. Pak J Med Sci, 29(2), 614-618.doi: 10.12669/pjms.292.3194

Oddy, W.E., Li, J., Whitehouse, A.J.O., Zubrick, S.R., \& Malacova, E. (2011). Breastfeeding duration and academic achievement at 10 years. Pediatrics, 127, 137-145.

Ogunsile, S.E. (2012). The effect of dietary pattern and body mass index on the academic performance of in school adolescents. International Education Studies, 5(6), 65-72. http://dx.doi.org/10.5539/ies.v5n6p65

Oğuz, Ş., \& Önay, D. (2011). Konya il merkezinde okul öncesi eğitim kurumlarma devam etmekte olan 60-72 aylık çocukların beslenme alışkanlikları. Selçuk Üniversitesi, Konya.

Oğuz, Ş., \& Önay Derin, D. (2013). 60-72 ayllk çocukların bazı beslenme alışkanlıklarının incelenmesi. Elementary Education Online, 12(2), 498-511.

Okan, M. \& Özdemir, Ö. (2005). Mental Reterdation in Children. Aktuel Pediatric, 3, 62-66.

Önay, D. (2002). Ankara'da farklı sosyo-ekonomik düzeylerdeki 14-15 yaş grubu öğrencilerin beslenme durumu ve bunu etkileyen bazı değişkenler. Ankara Üniversitesi, Ankara.

Özbaş, S., Uskun, E., Küçüksoku, B., Hocaoğlu, Ü., Akalın, S., \& Özbaş, H. (2018). Eğitilebilir zihinsel engelli çocukların besin tüketim kayıtlarına göre beslenme durumları. Akademik Gıda, 16(2), 192-196. doi: 10.24323/akademik-gida.449854

Özgüven, L. (2015). Zihinsel engelli çocuk ve adolesanları beslenme durumu ve alışkanlikları. Erciyes Üniversitesi, Kayseri.

Pisoschi, A.M.,Cheregi, M.C., \& Danet, A.F. (2009). Total antioxidant capacity of some commercial fruit juices: electro chemical and spectrophotometrical approaches. Molecules, 14(1), $480-$ 493.https://doi.org/10.3390/molecules140104 $\underline{80}$

Rezaei, M., Gharib, M., \& Lotfi, G. (2011). Prevalence of feeding problems in children with intellectual disability. Iranian Rehabilitation Journal, 9, 56-59.

Samur, G. (2008). Anne sütü (Ministry of Healt Publication No: 726). Ankara: Klasmat Yayıncilık.

Sa'nchez-Lastres, J.,Eirı's-Puñal, J.,Otero-Cepeda, J.L., Pavo'n-Belincho'n, P., \& Castro-Gago, M. (2003). Nutritional status of mentally retarded children in North West Spain: II. biochemical indicators. Acta Pediatr, 92, 928934.https://doi.org/10.1111/j.16512227.2003.tb00612.x

Sandberg, M., Ahlstrom, G., \& Kristensson, J. (2017). Patterns of somatic diagnoses in older people with intellectual disability: A Swedish eleven yearcase-control study of inpatient data. $J$ Appl Res Intellect Disabil, 30(1), 157-71.

Scheepers, M.,Kerr, M.,O'Hara, D., \& et al. (2005). Reducing health disparity in people with intellectual disabilities: a report from health issues special interestre search group of disabilities. Journal of Policy and Practice in Intellectual Disabilities, 2, 249255.https://doi.org/10.1111/j.17411130.2005.00037.x

Simila, S., \& Niskanen, P. (1991). Under weight and over weight cases amongst the mentally retarded. Journal of Mental Deficiency Research, $55,160-164$.

Suzuki, M. Saitoh, S. Tasaki, Y., Shimomura, Y., Makishima, R., \& Hosoya, N.(1991). Nutritional status and daily physical activity of handicapped students in Tokyo Metropolitan schools for deaf, blind, mentally retarded and physically handicapped individuals. Am J ClinNutr, 54,1101-

1111.https://doi.org/10.1093/ajcn/54.6.1101

Stewart. L. (2003). Development of theNutrition and Swallowing Checklist, a screening tool for nutrition risk and swallowing risk in people with intellectual disability. Journal of IntellectualeDevelopmental Disability, 28(2), 171-187, DOI: 10.1080/1366825031000106945 
Timimi, S., Douglas, J., \& Tsiftsopoulou, K. (1997). Selective eaters: A retrospective case note study. Child: care, health, and dev., 23, 265-278.

Turan, T. Ceylan, S.S. Çetinkaya, B., \& Altundağ, S. (2009). Meslek lisesi öğrencilerinin obezite sıklığının ve beslenme alışkanlıklarının incelenmesi. TAF Preventive Medicine Bulletin, $8(1), 5-12$.

Turan Gürhopur, F.D., \& İşler Dalgıç, A. (2017). Zihinsel yetersiz çocuğu olan ebeveynlerde aile yükü Journal of Psychiatric Nursing, 8(1), 9-16.

Turgut, M. Bayrak, E. \& Baş, M. (2014). Engelli çocukların ailelerinin beslenme bilgi ve davranışlarının belirlenmesi. International Journal of Science Culture and Sport, 2, 126135.https://dx.doi.org/10.14486/IJSCS184

Ünal, G. \& Özenoğlu, A. (2016). Nöro gelişimsel bozukluklarda beslenme. Clin Exp Health Sci, 6(2), 80-5.

Vançelik, S., Önal, S.G., Güraksın, A., \& Beyhun E. (2007). Üniversite öğrencilerinin beslenme bilgi ve alışkanlıkları ile ilişkili faktörler. TSK Koruyucu Hekimlik Bülteni, 6, 242-248

Vargün, R., Ulu, H., Duman, R., Yağmurlu, A., Erkir, G., Kacar, S., \& Özel, S. (2004). Serebralpalsili çocuklarda beslenme problemleri ve tedavisi. Journal of Ankara University Faculty of Medicine, 57, 257-265.

Varol, N. (2016). Aile eğitimi (5. Basım).Ankara: Kök Publishing.

Williams, K.E., Bridget, G.G., \& Schreck, K.A. (2005). Comparing selective eaters with and without developmental disabilities. Journal of Developmental and Physical Disabilities, 17(3), doi: 10.1007/s10882-005-4387-7

Whiteley, P., Rodgers, J., \& Shattock, P. (2000). Feeding patterns in Autism. Autism, 4,207211.

https://doi.org/10.1177/1362361300004002008

World Health Organization (WHO). (1980). World Report on Disability and Rehabilitation. Publish Data. (AccessDate: 21.04.2015). http://apps.who.int/iris/bitstream/handle/10665/ $41003 / 9241541261$

WHO (2013a), World Health Organization, HealthTopics, Nutrition, http://www.who.int/topics/nutrition/en/ (15.06.2013).
WHO (2013b), World Health Organization, 10 Facts on Nutrition, http://www.who.int/features/factfiles/nutrition/e n/index.html (15.06.2013).

Yıldırım, B. (2015). Hafif düzeyde zihinsel yetersizliği olan çocuklarm beslenme özellikleri ve aile etkileşimi. Necmettin Erbakan Üniversitesi, Konya.

Yılmaz, Ş.Y. (2011). Zihinsel engelli çocuklarda salya kontrolünün sağlanmasında oral motor terapinin etkililiği. Selçuk Üniversitesi, Konya. 